\title{
Realtà Aumentata con GIS e BIM a servizio dei processi di scelta complessa
}

\author{
Daniela De Luca \\ Umberto Mecca \\ Giuseppe Moglia \\ Manuela Rebaudengo
}

\begin{abstract}
L'articolo illustra, per i processi di scelta complessa, un quadro metodologico per il soddisfacimento di un bisogno, tipicamente pubblico, di una nuova opera o di un nuovo servizio. Abbandonando i modelli di scelta tradizionale, basati su un intreccio di informazioni di varia natura, spesso non sempre chiari e/o disponibili per l'utente, la ricerca propone l'utilizzo di un insieme avanzato di strumenti che permetta di scegliere consapevolmente, fruendo contemporaneamente di una serie di contenuti che possono popolare un modello digitale della città.

A partire da una breve introduzione sul tema della digitalizzazione del settore delle costruzioni, l'articolo esplora la possibilità di organizzare informazioni di varia natura all'interno di modelli digitali opportunamente progettati, per una gestione efficace e non ridondante dei dati a disposizione. Seguono specifici approfondimenti sugli strumenti che il modello propone di integrare (BIM, GIS, AR). Lo studio conclude sulle possibili applicazioni al campo delle politiche pubbliche, in particolare nei casi di scelta complessa di alternative di intervento (localizzative, funzionali, tecnologiche etc.).
\end{abstract}

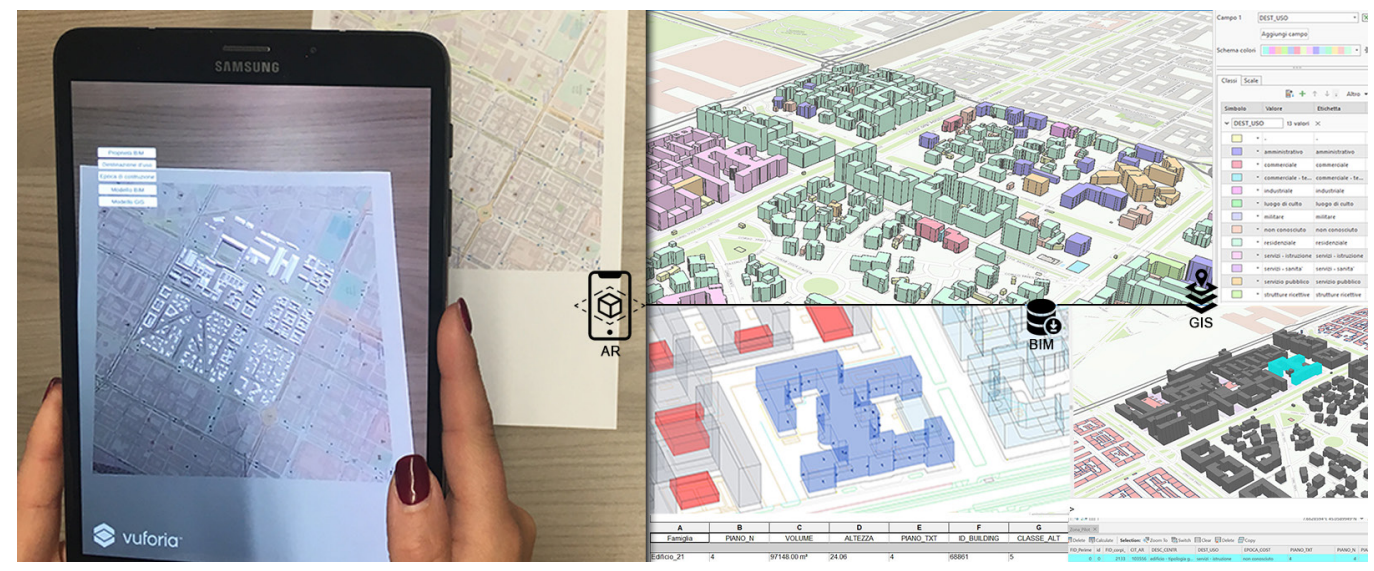




\section{Introduzione}

II territorio, inteso come un 'sistema complesso', è un insieme composto da elementi naturali e antropici che si influenzano vicendevolmente. Un sistema complesso in termini generali è definito come un "insieme di elementi variabili e fortemente interconnessi anche nella loro evoluzione temporale, sicché la conoscenza singola d'ognuno di essi non è sufficiente a stabilire l'evoluzione complessiva del sistema" [Enciclopedia della Matematica 20 I3, ad vocem]. Gli insediamenti umani con le loro unità abitative, produttive e infrastrutturali modificano i caratteri dell'ambiente su cui si inseriscono adattandolo alle proprie esigenze e utilizzando le risorse in esso contenute [Mecca et al. 2019]. Quindi, per garantire il funzionamento dell'intero sistema occorre che siano innanzitutto regolati i singoli sottosistemi che lo compongono. Questa operazione è svolta da appositi 'organi' che, operando a scale differenti, soddisfano specifiche 'necessità' avvalendosi di criteri e strumenti attraverso i quali sono in grado di effettuare scelte oggettive.

Nel caso di un'amministrazione pubblica una 'necessità' specifica è ad esempio quella di garantire il soddisfacimento di un bisogno (erogazione un servizio, realizzazione di un'opera, mantenimento della sicurezza dei cittadini ecc.), per cui potrebbe essere utile definire, in modo sintetico, una lista di priorità degli interventi, stilata in modo oggettivo. Per un 'organo' interessato, ad esempio, conoscere puntualmente lo Stato di Manutenzione (SM) delle infrastrutture e degli immobili in suo possesso (o in generale del territorio urbano e non) permette di ragionare in modo oggettivo per priorità, stilando una graduatoria degli interventi da effettuare.

Più in generale, in un'epoca in cui scarseggiano i finanziamenti per opere e servizi, la necessità di operare una scelta tra due o più alternative di investimento (diverse funzioni, diverse localizzazioni, diverse tipologie di immobili, ecc. è una esigenza sempre più frequente per portatori di interesse pubblici e privati. È possibile immaginare che questa scelta possa avvenire in un modo più partecipativo e condiviso, anche con la popolazione, ad esempio utilizzando strumenti di rappresentazione dei dati ormai ampiamente diffusi nel settore delle costruzioni?
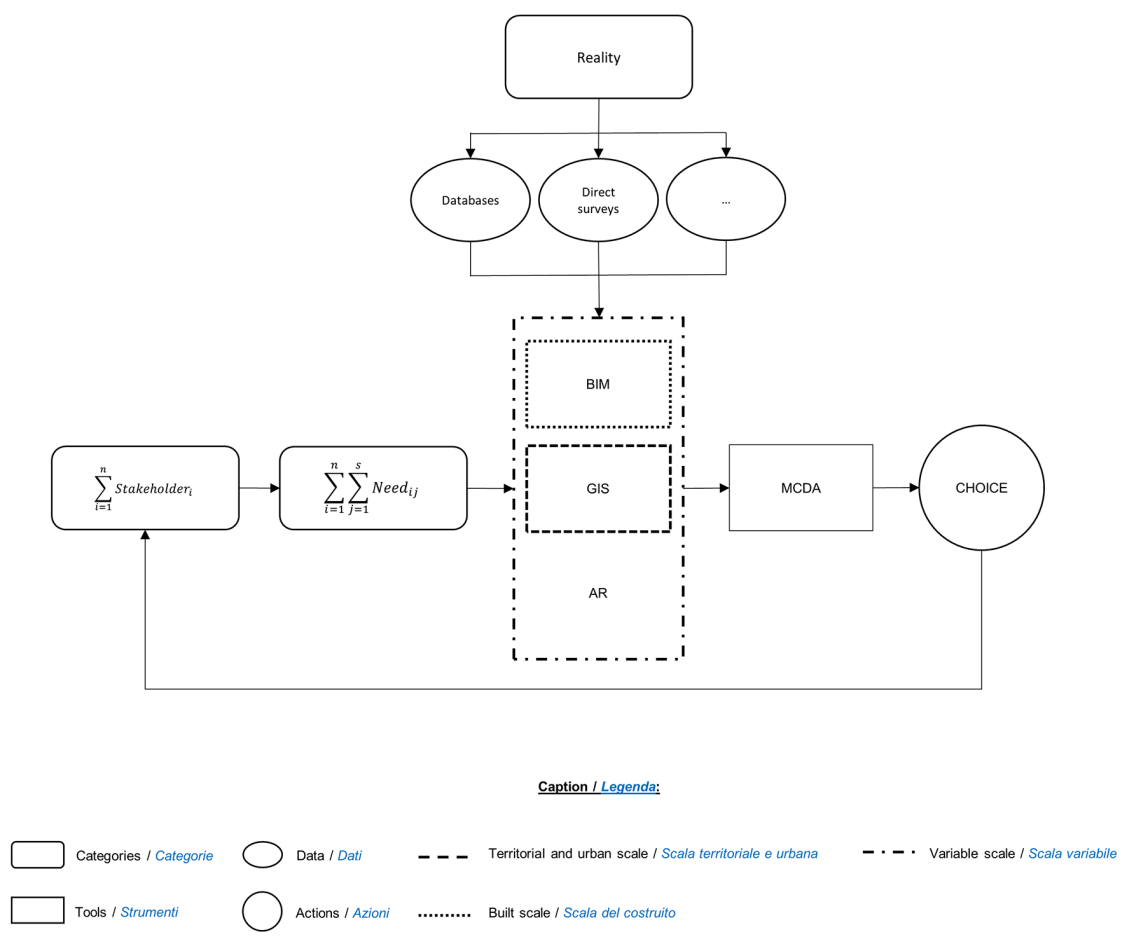


\section{Metodo}

Per rispondere a questa domanda, nel lavoro di ricerca qui riportato, si è definito un possibile processo da utilizzare nel caso si debbano affrontare necessità (puntuali o diffuse) riguardanti il sistema delle costruzioni. Su di esso operano numerosi portatori di interesse e gli elementi che lo costituiscono possono esser raggruppati principalmente in due macro-categorie: le infrastrutture e gli immobili. Ipotizzando un processo come quello descritto in figura I, la prima fase consiste nel reperimento dei dati, necessari e sufficienti a descrivere le caratteristiche degli elementi coinvolti. Le fonti da cui estrapolare i dati in entrata possono essere reperite consultando banche dati esistenti e certificate come quelle delle amministrazioni pubbliche o degli istituti di ricerca, oppure attraverso operazioni di rilievo diretto a cura di professionisti con formazione specifica.

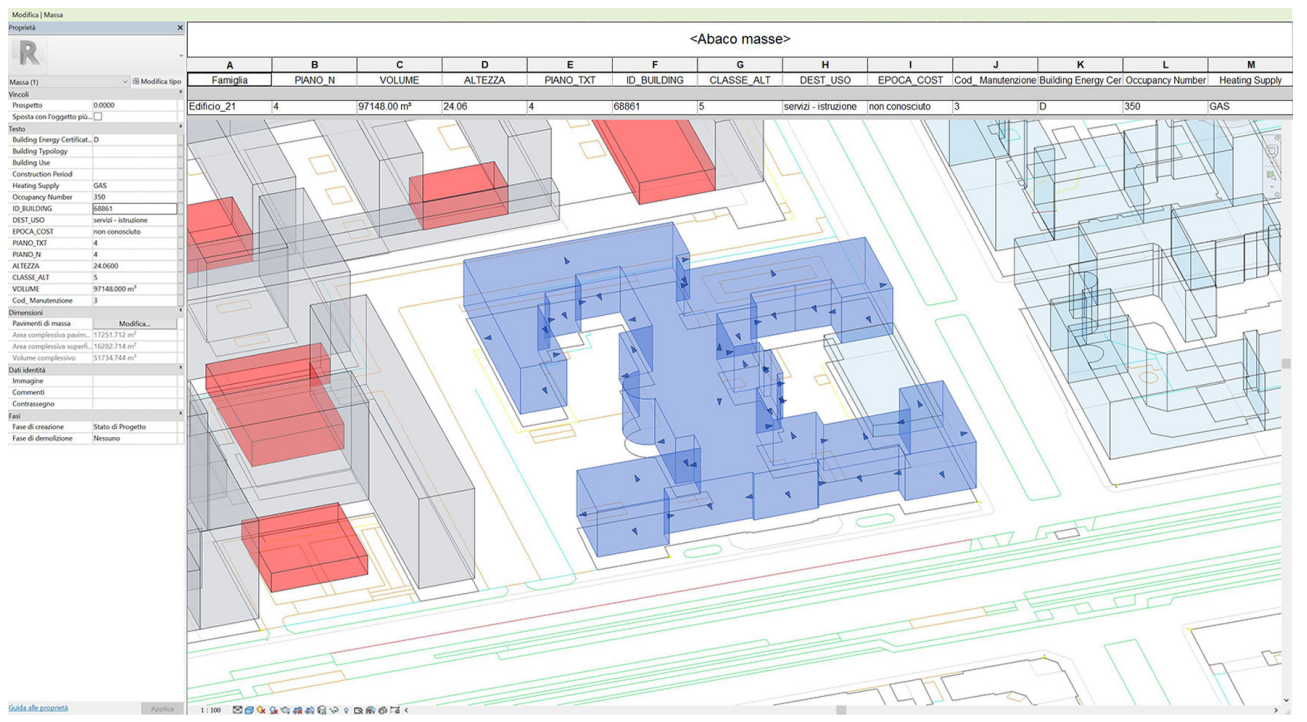

Data la numerosità dei dati a disposizione, per una gestione efficace e non ridondante dei medesimi, è necessario organizzarli all'interno di modelli digitali opportunamente progettati. Questi ultimi, a seconda delle necessità e degli obiettivi da raggiungere, sono realizzabili con strumenti differenti, GIS (Geographic Information System) oppure BIM (Building Information Modelling), in funzione della scala di approfondimento: urbana e territoriale o del costruito. Per trattare successivamente i dati occorre agire direttamente sugli applicativi dei software utilizzati per la creazione dei modelli, attraverso appositi algoritmi di calcolo che, al loro interno, utilizzano coefficienti in grado di 'pesare' opportunamente i dati di input, in funzione dell'obiettivo dell'indagine. Ad esempio, volendo determinare un indice sintetico sullo stato di manutenzione del costruito, della viabilità ecc., ovvero di un territorio, occorrerà filtrare in modo gerarchico i dati in entrata per considerare solo gli elementi che impattano sullo stato di manutenzione. La consultazione e la visualizzazione dei dati di output derivanti dalle elaborazioni effettuate, può esser svolta direttamente attraverso i software utilizzati per la realizzazione dei modelli oppure, in maniera molto più agevole e intuitiva, attraverso la creazione di scenari di Realtà Aumentata (AR).

Infine, dopo aver definito e valutato più caratteristiche degli elementi appartenenti al sistema considerato, è necessaria una pesatura di livello, per generare un ordine di priorità degli interventi, con l'obiettivo di agevolare gli organi di gestione nella scelta [Prizzon et al. 2006]. Sono poi definiti gli strumenti utilizzabili per la realizzazione di modelli digitali (BIM, GIS) quali supporto ai metodi di aiuto alla decisione, utilizzabili per l'ordinamento dei dati in entrata e per la gerarchizzazione dei risultati e infine la tecnologia della AR utilizzabile per una chiara visualizzazione dei dati contenuti nei modelli sviluppati. 


\section{Modelli digitali come strumento per semplificare problemi di scelta complessa}

\section{Il problema delle scelte per l'attuazione delle politiche pubbliche}

C'è chi sostiene che le criticità riscontrabili nel sistema italiano delle opere pubbliche (in fase di realizzazione e di esercizio) derivino principalmente dalla frammentazione amministrativa del territorio nazionale; chi, invece, ritiene che le problematiche nascano spesso dal carattere politico mediatico degli interventi, non solo delle cosiddette piccole opere. Quando gli attori in gioco sono tanti, con svariate competenze e soprattutto quando la scelta di intervento non è banale, è ancora necessario un supporto per scegliere le opere su cui investire e per stimarne preventivamente le ricadute territoriali. In questi casi certamente saranno utilizzati strumenti e metodi estimativi, quali ad esempio le analisi multicriteri (MCDA, Multi Criteria Data Analysis), il Public Sector Comparator (PSC) e la Value for Money Analysis (VfMA), oppure più in generale le analisi dei flussi di cassa (DCFA, Discounted Cash Flow Analysis) [Prizzon, Rebaudengo 20 15]. Molti di questi vengono utilizzati con successo quali strumenti di supporto alla decisione per scelte strategiche di grandi progetti di trasformazione che possono coinvolgere, ad esempio, le aree metropolitane o territori più estesi, nel caso di opere a rete.

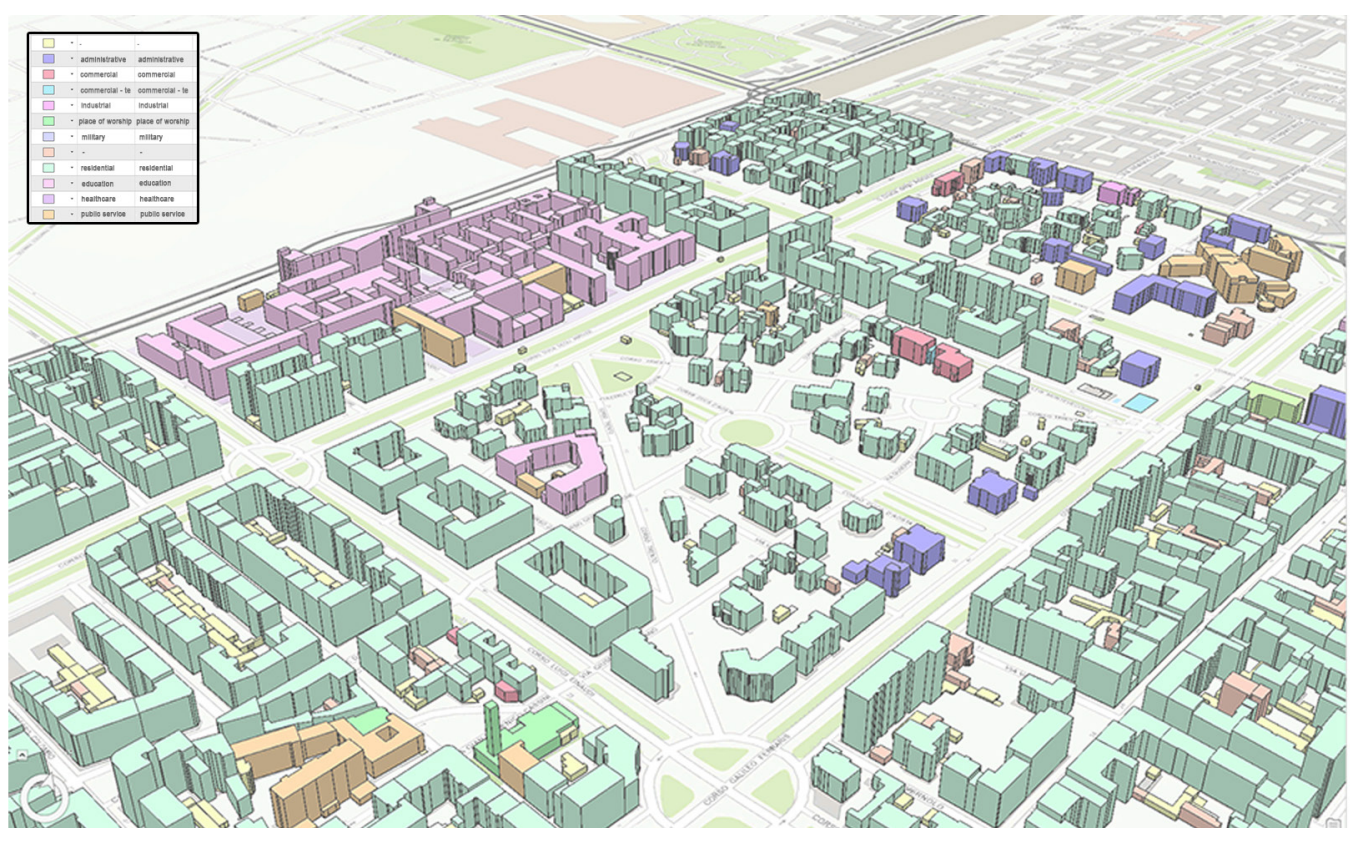

Quale supporto da parte di GIS e BIM?

L'avento delle nuove tecnologie ha cambiato notevolmente la progettazione e la manutenzione degli edifici, soprattutto nel modo di comunicare le informazioni e di rappresentare le forme. La penna, la matita e la carta sono stati sostituiti da nuovi strumenti in grado di agevolare non solo la fase di ideazione e realizzazione, ma anche la semplificazione di interventi sui singoli edifici e sul tessuto edilizio. II BIM è un esempio: la digitalizzazione delle informazioni nel modello tridimensionale permette di sviluppare modelli virtuali affini alle esigenze degli utenti e studiare scenari migliorativi, trasformando gli elementi in veri e propri Digital Twins (DT) [Moglia et al. 20 19]. L'automatizzazione e l'integrazione in tempo reale delle informazioni porta a definire un modello collaborativo nel quale più attori possono interagire tra loro e ridefinire il flusso dei dati [Hardin 2009]. II BIM, in questi termini, permette di formare la carta d'identità del manufatto, descrivendo e catalogando tutta la documentazione disponibile senza interruzioni o perdita di dati. Si tratta quindi di definire un modello nel quale la conoscenza 
del patrimonio è finalizzata a diversi ambiti tra cui la sicurezza, la qualità, la riduzione del fabbisogno di risorse economiche e la programmazione puntuale di interventi manutentivi. Inoltre, l'accessibilità a più utenti, rende il processo interoperabile e condivisibile tra le diverse figure coinvolte [Moglia et al. 20 I 8]. In particolare, integrando all'interno di piattaforme BIM, le geometrie e le proprietà alfanumeriche provenienti dal modello territoriale GIS, per ogni singolo edificio è possibile formare abachi correlati con parametri globali estrapolati da banche dati generali fino al dettaglio informativo per la parte di manutenzione e gestione del fabbricato come evidenziato in figura 2. Questi dati specifici possono arricchire il database che popolerà il modello virtuale visualizzabile tramite la AR.

La conoscenza di un edificio, delle sue trasformazioni nel tempo [Osello et al. 2017] e il rapporto con il contesto, owvero la città e gli abitanti, sono informazioni e contenuti che un modello digitale può rappresentare in modo efficace, soprattutto nei processi di scelta, in cui per poter prendere la decisione si devono spesso considerare contemporaneamente molti aspetti e dati.

Come già visto per il BIM, anche il GIS può essere definito un sistema informativo basato su tecniche informatiche in grado di acquisire, memorizzare, aggiornare, modellizzare, manipolare, estrarre, analizzare e presentare in forma multimediale dati a referenza geografica [Worboys, Duckham 2004]. In generale, è possibile distingue tra due tipologie di GIS, quelli descrittivi, utili agli enti che svolgono attività di programmazione o di pianificazione del territorio, e quelli a carattere prevalentemente gestionale, indirizzati agli enti che svolgono uno specifico servizio. Alcuni esempi di GIS descrittivi sono i sistemi informativi territoriali a livello regionale $(1: 5.000,1: 10000)$, mentre i gestionali possono essere quelli per la gestione delle reti tecnologiche, come le reti idriche, quelle fognarie o, ancora, quelle per l'approvigionamento dell'energia. A scala urbana, invece, i GIS possono permettere di raccogliere e rappresentare informazioni specifiche sui singoli edifici che compongono il modello.

AR come 'plus' del modello di scelta.

Con la $A R$, sovrapponendo agli oggetti del mondo reale dei contenuti virtuali, è possibile visualizzare e instaurare nuove relazioni spaziali complesse poi utilizzate per lo sviluppo di tecnologie innovative a supporto di questa nuova realtà [Klopfer et al. 2007]. Ogni oggetto presente nell'ambientazione reale può essere identificato tramite un'immagine, e connesso all'interno di una rete per comunicare informazioni con altri oggetti, realizzando un'infrastruttura nella quale la realtà diviene il contenitore di raccolta dati ed esigenze dei diversi utenti. I sistemi che utilizzano questa infrastruttura sono in grado di supportare gli addetti nella conoscenza e nella catalogazione dei dati degli edifici o del territorio, controllando le informazioni che provengono da banche dati differenti. La AR è oggi il nesso materiale tra tecnologia, infor-

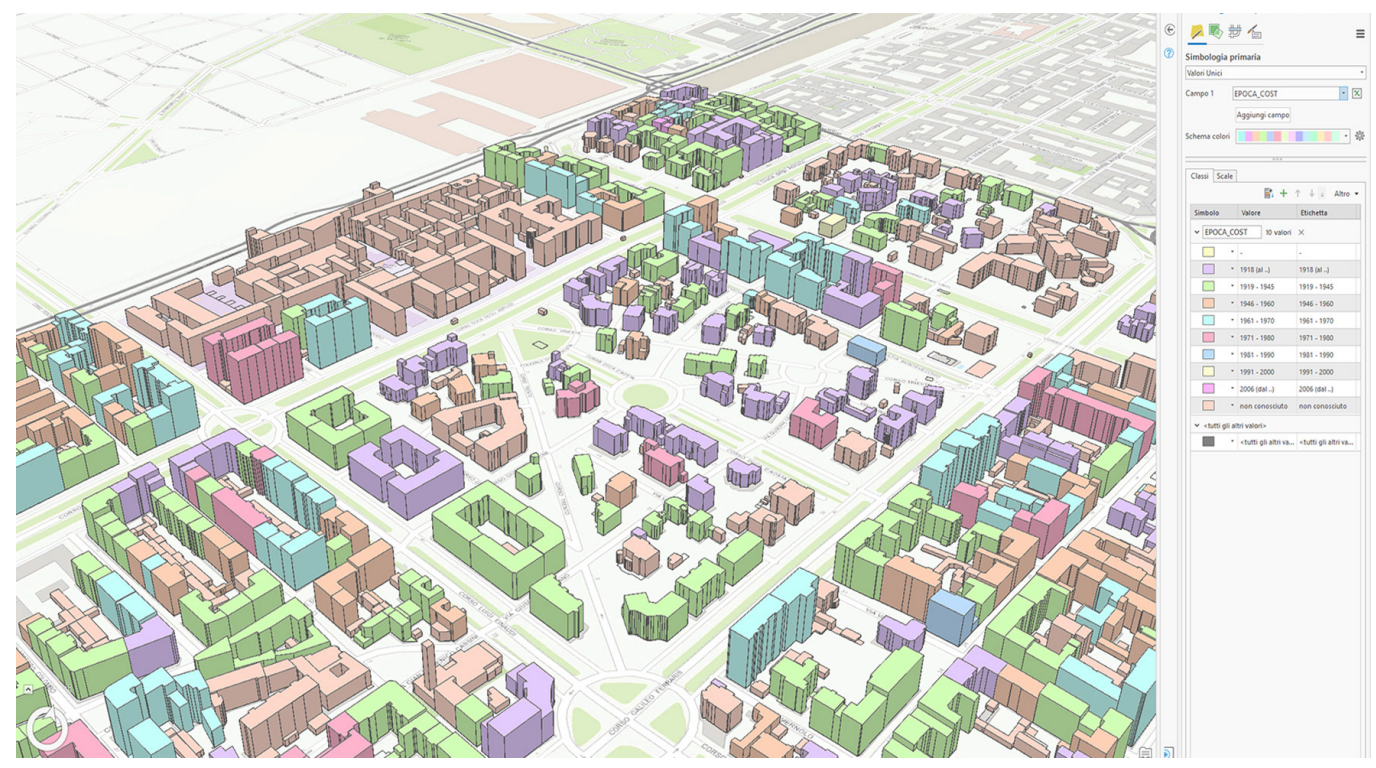


mazione e codici, grazie a configurazioni spaziali specifiche. In particolare, l'aumento dei dati generati da molteplici utenti, offre l'opportunità di studiare nuove forme di rappresentazioni digitali legate ai continui mutamenti sociali [Graham et al. 20I2]. Infine, è possibile connettere sempre di più le rappresentazioni urbane con il singolo manufatto. La AR diviene quindi un contenitore di dati alfanumerici e geometrici nel quale ogni singola azione, effettuata tramite sequenza di istruzioni, mette in relazione i dati estrapolati da database esterni e ne riproduce tramite indicizzazioni cromatiche la corretta visualizzazione sul modello geometrico come si evince dalla figura 5.

Allo stesso modo per ogni singolo edificio è possibile visualizzare i dati specifici provenienti da modelli BIM, sovrapponendo al modello reale le informazioni, ad esempio manutentive, conservative e gestionali, che il modello digitale raccoglie. II vantaggio di questa tipologia di visualizzazione è di poter confrontare la affidabilità delle informazioni per programmare, nell'esempio, interventi mirati per ridurre il degrado e incentivare la manutenzione ordinaria. Grazie all'interoperabilità tra dati provenienti dal GIS e dal BIM, la AR restituisce e cataloga in maniera sistematica tutte quelle informazioni necessarie per integrare i tradizionali metodi di rappresentazione. In questo senso appare estremamente interessante il suo utilizzo nel momento della scelta.

\section{Conclusioni}

Lo studio, fin qui condotto in via teorica, evidenzia che in funzione degli attori coinvolti e del sistema analizzato potranno esser soddisfatte molteplici necessità, progettando e attuando opportuni processi di lavoro. Questi ultimi, organizzati per fasi, devono esser in grado di descrivere gli elementi interessati e di dominare le numerose variabili coinvolte, portando ad una semplificazione del problema iniziale e fornendo criteri oggettivi con cui operare delle scelte. La ricerca attenta e dettagliata delle informazioni disponibili (dei fabbricati, del territorio, delle infrastrutture ecc.), da assemblare in un'unica banca dati, facilita l'accessibilità e riduce gli errori sistematici. Per quanto riguarda il settore immobiliare privato, ad esempio, tra le banche dati esistenti utili al popolamento del modello vi sono quelle gestite dagli enti territoriali o da pubbliche amministrazioni. Alcune delle più interessanti sono quelle dell'Osservatorio del Mercato Immobiliare e del Catasto (Agenzia delle Entrate); la banca dati sugli interventi di miglioramento energetico dell'ENEA (Agenzia nazionale per le nuove tecnologie, l'energia e lo sviluppo economico sostenibile); quelle dell'ISTAT (Istituto Nazionale di Statistica), che contengono informazioni sui consumi e sulle abitudini delle famiglie.
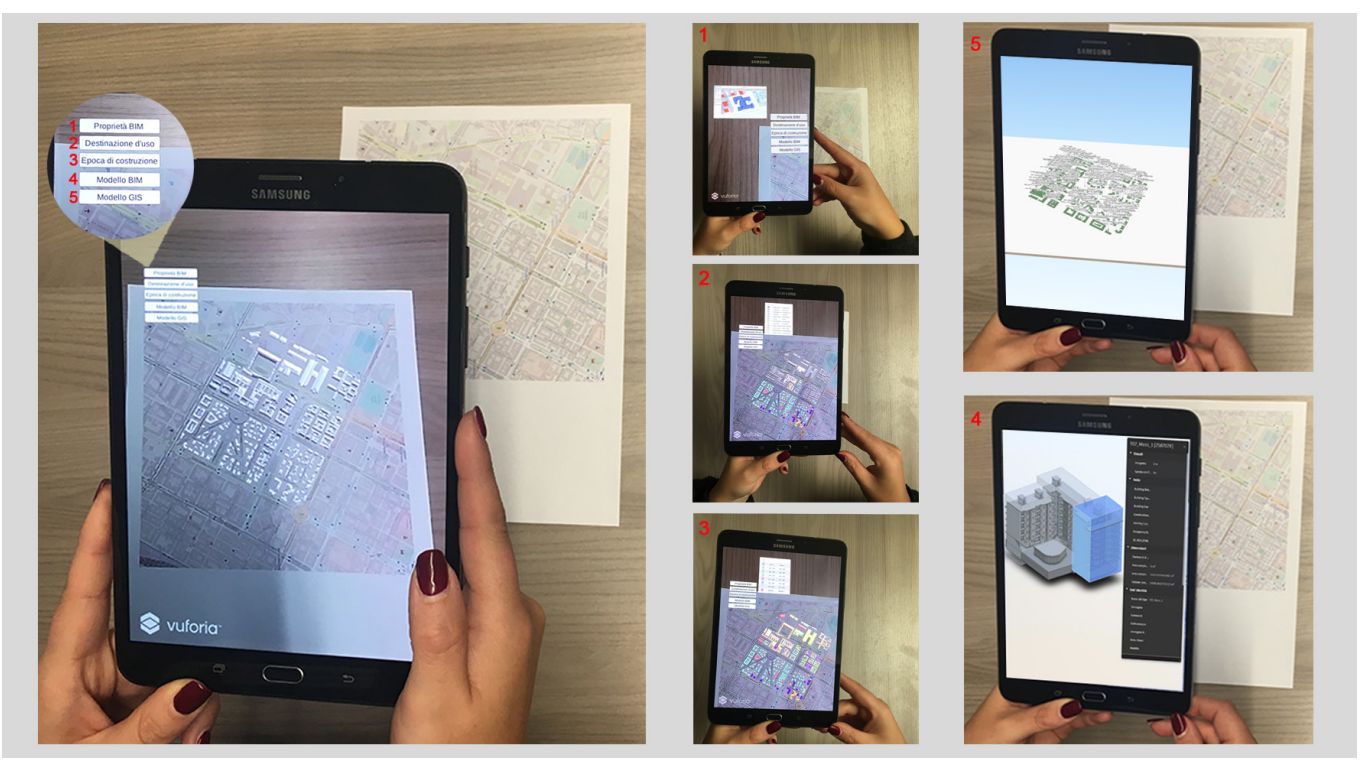
Futuri sviluppi della ricerca intendono provare il modello su un caso semplice di scelta localizzativa nell'area della città di Torino, con una misura della percezione, su un campione di utenti della collettività, delle opportunità e del grado di supporto nella scelta offerti dall'insieme degli strumenti analizzati. Le ampie possibilità di fruizione e la sua capacità di far memorizzare codici da parte degli utilizzatori [Ismail et al. 2009] fanno dell'ambiente AR, uno spazio virtuale collaborativo e interattivo che può far dialogare i cittadini tramite interfacce personalizzate e renderli così più partecipi delle scelte che le politiche pubbliche operano all'interno del contesto, in questo caso urbano. Inoltre, i molteplici database possono essere filtrati e modificati utilizzando la AR come semplice cruscotto di visualizzazione. Le modifiche sono trasferite all'interno di una piattaforma comune che processa e trasforma i big data in sistemi informativi flessibili. Molteplici enti operativi sono in grado di instaurare nuove relazioni in armonia con il contesto circostante, valutando ad esempio le correlazioni tra fabbricati, utenti e informazioni provenienti da database eterogenei e disaggregati [Wang et al. 2012].

\section{Riferimenti bibliografici}

Azhar Salman (20II). Building Information Modeling (BIM): Trends, Benefits, Risks, and Challenges for the AEC Industry. In Leadership and Management in Engineering, volume II, issue 3, pp. 24I-252.

Enciclopedia della Matematica Treccani (20 I3). Ad vocem: <http://www.treccani.it/enciclopedia/sistema-complesso_\%28Enciclopedia-della-Matematica\%29/>.

Graham Mark, Zook Matthew, Boulton Andrew (2012). Augmented reality in urban places: contested content and the duplicity of code. In Transactions of Geographical Information Science, volume 38, issue 3, pp. 464-479.

Hardin Brad (2009). BIM and Construction Management: Proven Tools, Methods, and Workflows. Hoboken: John Wiley \& Sons.

Ismail Ajune Wanis, Bin Mohd Shahrizal (2009). Collaborative Augmented Reality: Multi-user Interaction in Urban Simulation. In Halimah Badioze Zaman et al. (eds.). IVIC '09: Proceedings of the I st International Visual Informatics Conference on Visual Informatics: Bridging Research and Practice. Kuala Lumpur (Malaysia), I I- 3 novembre 2009, pp. 37 I-39I. Berlino: Springer.

Klopfer Eric, Squire Kurt (2008). Environmental Detectives: the development of an augmented reality platform for environmental simulations. In Educational Technology Research and Development, 56, pp. 203-228.

Mecca Umberto et al. (2019). Mapping maintenance regulations: a methodological framework to improve territorial resilience. In 19th International Multidisciplinary Scientific GeoConference SGEM 20 19. 2. Hydrology and Water Resources, pp. 229-244.

Moglia Giuseppe, Del Giudice Matteo, Rebaudengo Manuela (2018). The model of the city: data variety, operability and interfaces. In Salerno Rossella (a cura di). Rappresentazione/Materiale/lmmateriale. Atti del $40^{\circ}$ Convegno Internazionale dei Docenti delle Discipline della Rappresentazione. Milano I3-I5 settembre, pp. I83- I86. Roma: Gangemi.

Moglia Giuseppe, Rebaudengo Manuela, Ruffino Pablo Angel (2019). “Digital Twin”' Utopia? In Belardi Paolo (a cura di). Riflessioni. L'arte del disegno / II disegno dell'arte Atti del $40^{\circ}$ Convegno Internazionale dei Docenti delle Discipline della Rappresentazione. Perugia 19-2I settembre 2019, pp. 1297-1302. Roma: Gangemi.

Osello Anna, Ugliotti Francesca Maria (20 I7). BIM verso il catasto del futuro; Conoscere, digitalizzare, condividere. Il caso studio della città di Torino. Roma: Gangemi.

Prizzon Francesco et al. (2006). La programmazione di opere pubbliche in Piemonte: il caso dei programmi integrati di sviluppo locale (P.I.S.L.). In Atti della XXVII Conferenza Italiana di Scienze Regionali (AISRe). Pisa I2-I4 ottobre 2006.

Prizzon Francesco, Rebaudengo Manuela (20I5). Quale futuro per la valutazione degli investimenti pubblici? Click Day vs. Selezione. In LaborEst, n. I0, pp. 242 I-3187. <http://pkp.unirc.it/ojs/index.php/LaborEst>.

Wang Xiangyu et al. (2012). A conceptual framework for integrating building information modeling with augmented reality. In Automation in Construction, volume 34, pp. 37-44.

Worboys Michael F., Duckham Matt (2004). GIS: A Computing Perspective. Boca Raton: CRC Press.

\section{Autori}

Daniela De Luca, Politecnico di Torino, daniela.deluca@polito.it

Umberto Mecca, Politecnico di Torino, umberto.mecca@polito.it

Giuseppe Moglia, Politecnico di Torino, giuseppe.moglia@polito.it

Manuela Rebaudengo, Politecnico di Torino, manuela.rebaudengo@polito.it

Per citare questo capitolo: De Luca Daniela, Mecca Umberto, Moglia Giuseppe, Rebaudengo Manuela (2020). Realtà Aumentata con GIS e BIM a servizio dei processi di scelta complessa/Augmented Reality with GIS and BIM at the service of complex choice processes. In Arena A., Arena M., Brandolino R.G., Colistra D., Ginex G., Mediati D., Nucifora S., Raffa P. (a cura di). Connettere. Un disegno per annodare e tessere. Atti del $42^{\circ}$ Convegno Internazionale dei Docenti delle Discipline della Rappresentazione/Connecting. Drawing for weaving relationships. Proceedings of the 42th International Conference of Representation Disciplines Teachers. Milano: FrancoAngeli, pp. 390-403. 


\title{
Augmented Reality with GIS and BIM at the Service of Complex Choice Processes
}

\author{
Daniela De Luca \\ Umberto Mecca \\ Giuseppe Moglia \\ Manuela Rebaudengo
}

\section{Abstract}

The paper illustrates, for complex choice processes, a methodological framework for satisfying a typically public need for a new work or a new service. Leaving traditional models of choice, based on a set of information of various kinds, often not always clear and/or available to the user, the research proposes the use of an advanced toolkit that allows to choose 'consciously', enjoying at the same time a series of contents that can form a digital model of the city.

Starting from a short introduction on digitization theme of the construction sector, the paper explores the possibility of organizing information of various kinds within specifically designed digital models, for an effective and non-redundant management of available data. Specific insights follow on the tools that the model proposes to integrate (BIM, GIS, AR). The study concludes with the possible applications in the field of public policies, particularly in cases of complex choice of intervention alternatives (location, functional, technological etc.).

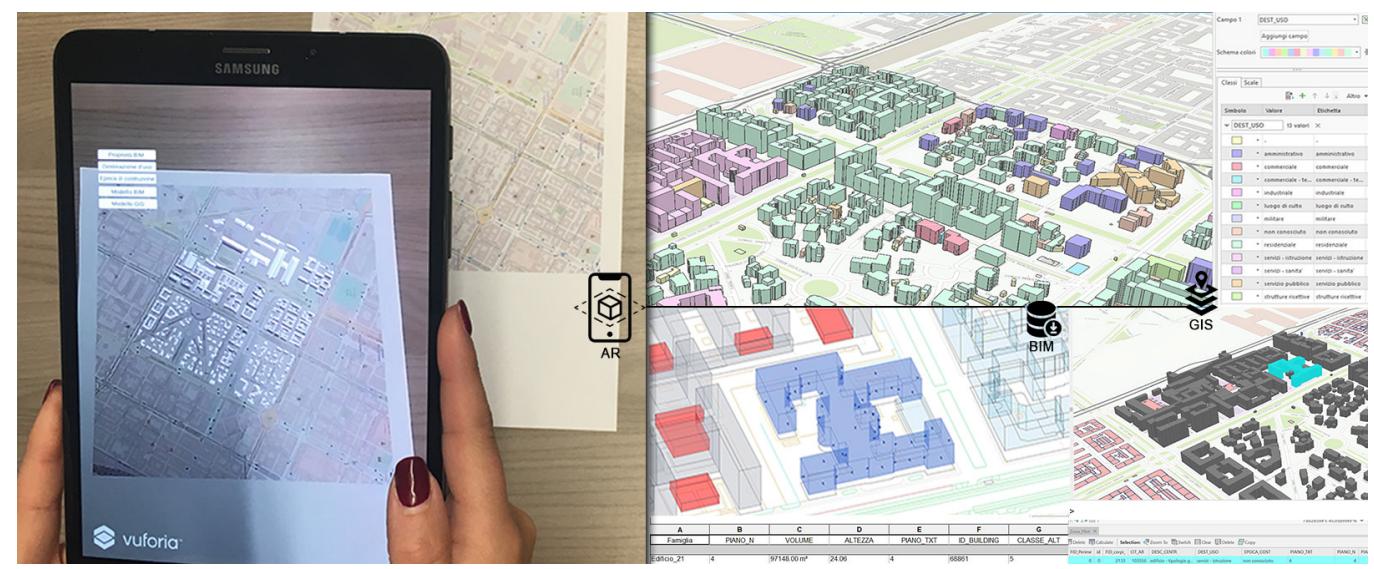




\section{Introduction}

The territory, understood as a 'complex system', is a set composed of natural and anthropic elements that influence each other. A complex system in general terms is defined as a "set of variable elements and strongly interconnected also in their temporal evolution, so the individual knowledge of each of them is not sufficient to establish the overall evoIution of the system" [Encyclopedia of Mathematics 20 I3, ad vocem]. Human settlements with their housing, production and infrastructure units modify the characteristics of the environment in which they are inserted, adapting it to their needs and using the resources contained therein [Mecca et al. 2019]. Therefore, to ensure the functioning of the entire system, the individual subsystems that compose it must first be regulated. This operation is carried out by specific 'bodies' which, operating at different scales, satisfy specific 'needs' using criteria and tools through which they are able to make objective choices. In the case of a public administration, a specific 'need' is, for example, that of guaranteeing the satisfaction of a need (provision of a service, realization of a work, maintenance of citizens safety, etc.), so it could be useful to define, in a synthetic way, a priority list of the interventions, objectively drawn up. For an interested 'body', for example, knowing exactly the State of Maintenance (SM) of the infrastructures and buildings in its possession (or in general of the urban and non-urban territory) allows to reason objectively by priority, drawing up a ranking of the interventions to be carried out.

More generally, in an era in which funding for works and services is scarce, the need to make a choice between two or more investment alternatives (different functions, different locations, different types of buildings etc.) is an ever increasing need for public and private stakeholders. Is it possible to imagine that this choice could take place in a more participatory and shared way, also with the population, for example by using data representation tools now widely used in the construction sector?

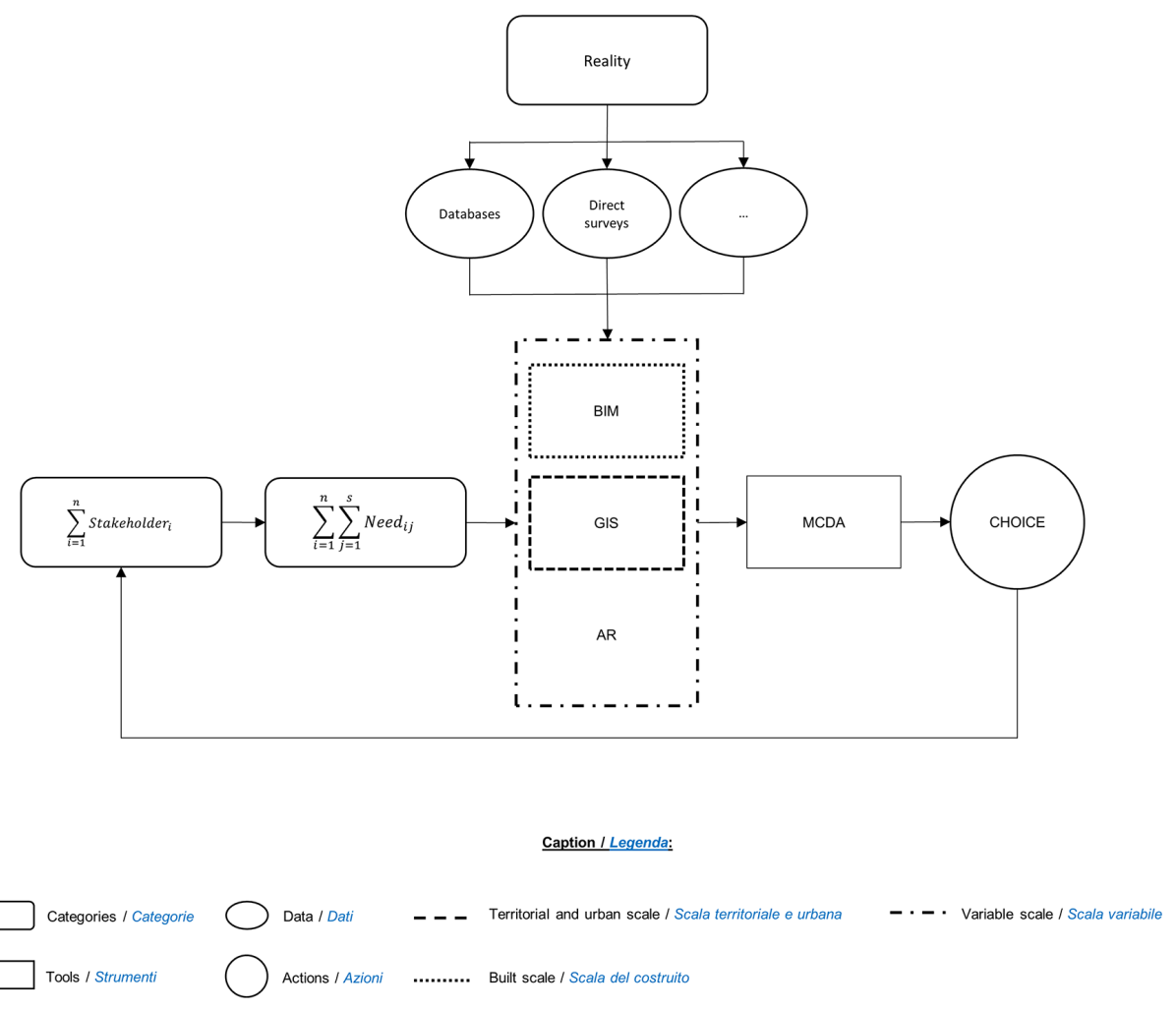




\section{Method}

To answer this question, in the research work reported here, a possible process has been defined to be used in the case of needs (punctual or widespread) concerning construction system. Numerous stakeholders operate on it and the elements that constitute it can be grouped mainly into two macro-categories: infrastructure and real estate. Assuming a process such as that described in figure I, the first phase consists in finding data, necessary and sufficient to describe the characteristics of involved elements. Sources from which to extrapolate incoming data can be found by consulting existing and certified databases such as those of public administrations or research institutes, or through operations of direct survey by professionals with specific training.

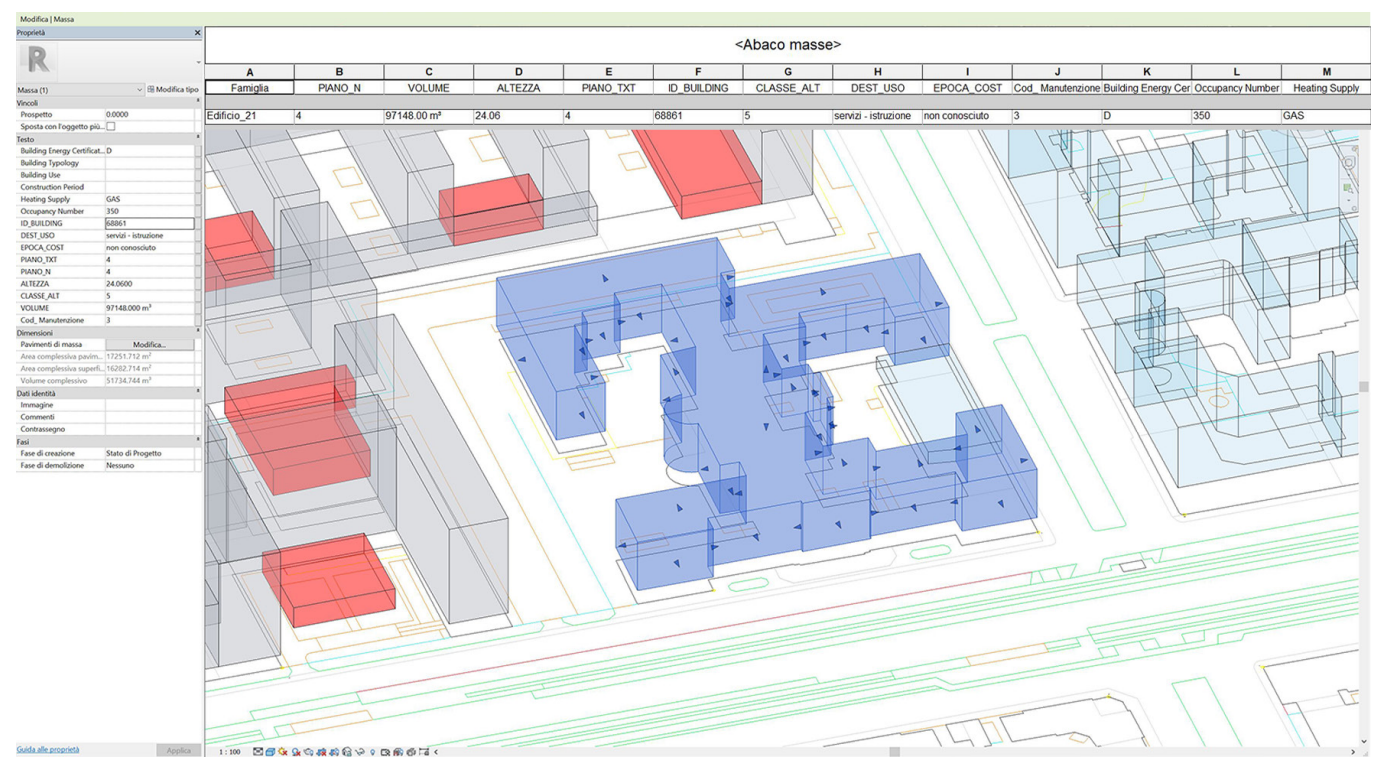

Given the number of data available, for effective and non-redundant management of the same, it is necessary to organize them within suitably designed digital models. The latter, depending on needs and objectives to be achieved, can be realized with different tools, GIS (Geographic Information System) or BIM (Building Information Modelling), depending on the scale of study: urban and territorial or built.

To subsequently process data, it is necessary to act directly on applications of the software used to create the models, through special calculation algorithms which, within them, use coefficients capable of appropriately 'weighing' the input data, according to objective of the investigation. For example, to determine a synthetic index on the state of maintenance of the building, roads, etc., or of a territory, it will be necessary to filter incoming data hierarchically to consider only elements that impact on the state of maintenance. Consultation and visualization of output data deriving from driven elaborations, can be carried out directly through the software used to realize the models or, in a much easier and more intuitive way, through the creation of Augmented Reality (AR) scenarios.

Finally, after defining and evaluating more characteristics of the elements belonging to system in question, level weighing is necessary to generate a priority order of interventions, with the aim of facilitating management bodies in choosing [Prizzon et al. 2006].

The tools that can be used to realize digital models (BIM, GIS) are then defined as support for decision-making methods, which can be used for sorting of incoming data and for hierarchization of results and, finally, as support for AR technology that can be used to clearly visualize data contained in the models developed. 


\section{Digital models as a tool to simplify complex choice problems}

The problem of choices for the implementation of public policies

There are those who argue that the critical issues found in the Italian public works system (under construction and in operation) mainly derive from the administrative fragmentation of the national territory; who, instead, believes that problems often arise from the political media nature of interventions, not only of so-called small works. When actors involved are many, with various skills and especially when the choice of action is not common, it is still necessary support to choose works in which to invest and to estimate in advance their territorial impact. In these cases, tools and estimation methods will certainly be used, such as the multicriteria analysis (MCDA, Multi Criteria Data Analysis), the Public Sector Comparator (PSC) and the Value for Money Analysis (VfMA), or more generally the analysis of the cash flows (DCFA, Discounted Cash Flow Analysis) [Prizzon \& Rebaudengo 2015]. Many of these are successfully used as decision support tools for strategic choices of large transformation projects that can involve, for example, metropolitan areas or larger territories, in the case of network works.

Fig. 3. GIS model with parameters related to intended use

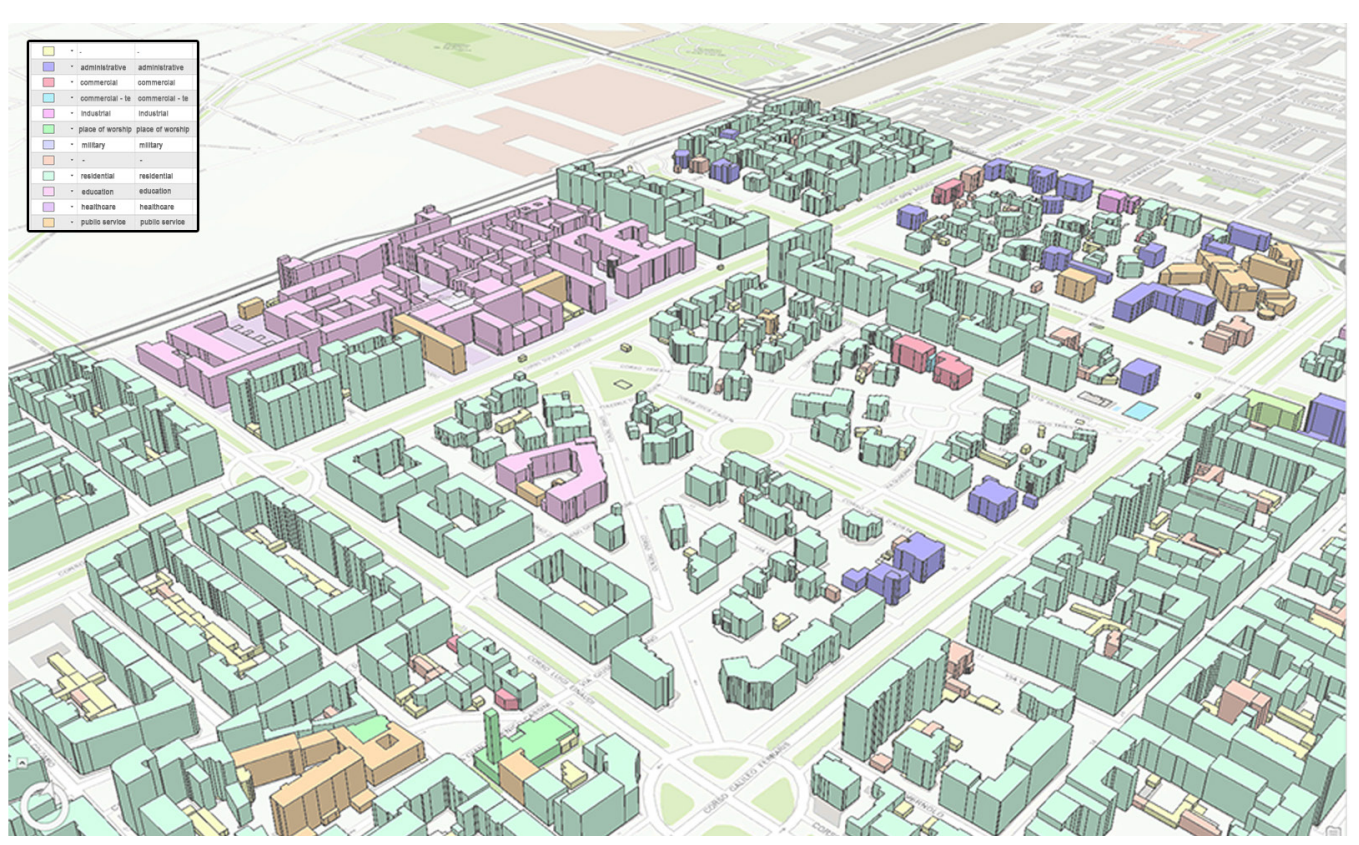

What support from GIS and BIM?

New technologies have significantly changed design and maintenance of buildings, especially in the way of communicating information and representing forms. Pen, pencil and paper have been replaced by new tools that can facilitate not only conception and realization phase, but also simplification of interventions on single buildings and on buildings texture. $\mathrm{BIM}$ is an example: the digitalization of information in the three-dimensional model allows to develop virtual models near to users' needs and to study improvement scenarios, transforming the elements into real Digital Twins (DT) [Moglia et al. 2019]. Automation and real-time integration of information leads to define a collaborative model in which multiple actors can interact with each other and redefine the flow of data [Hardin B. 2009]. In these terms, BIM allows to form identity card of the artefact, describing and cataloging all available documentation without interruption or loss of data. It is therefore a question of defining a model in which knowledge of the heritage is aimed at various areas including safety, qua- 
lity, reduction of the need for economic resources and precise planning of maintenance interventions. In addition, accessibility to multiple users makes the process interoperable and shareable between the different actors involved [Moglia et al. 20।8]. In particular, by integrating geometries and alphanumeric properties from GIS territorial model within BIM platforms, for each individual building it is possible to form schedules related to global parameters extrapolated from general databases, up to detailed information for maintenance and management as shown in figure 2. These specific data can enrich the database that will populate the virtual model viewable through the AR.

The knowledge of a building, of its transformations over time [Osello et al. 2017] and of its relationship with the context, i.e. city and inhabitants, are information and contents that a digital model can represent effectively, especially in the processes of choice, in which many aspects and data must be considered simultaneously in order to make the decision.

As already seen for BIM, also GIS can be defined as an information system based on IT techniques capable of acquiring, storing, updating, modeling, manipulating, extracting, analysing and presenting in a multimedia way data with geographical reference [Worboys, Duckham 2004]. In general, it is possible to distinguish between two types of GIS, the descriptive ones, useful to bodies that carry out scheduling or territorial planning activities, and those mainly of a managerial nature, addressed to bodies that perform a specific service. Some examples of descriptive GIS are territorial information systems at regional level (I:5.000, I: I0000), while the management ones can be those for management of technological networks, such as water and sewage networks or, again, those for energy supply. On an urban scale, instead, GIS can allow collection and representation of specific information on single buildings that form the model.

AR as the 'plus' of the model of choice

With $A R$, by superimposing virtual contents on real world objects, it is possible to visualize and establish new complex spatial relationships which are then used to develop innovative technologies to support this new reality. [Klopfer et al. 2007]. Each object current in real environment can be identified through an image and connected within a network to communicate information with other objects, creating an infrastructure in which reality becomes the container for collecting data and needs of different users. The systems that use this infrastructure can support employees in knowing and cataloguing of building or territory data, checking information that comes from different databases. AR is today the material link between technology, information and codes, thanks to specific spatial configurations. In particular, increase in data generated by multiple users offers the opportunity to study new

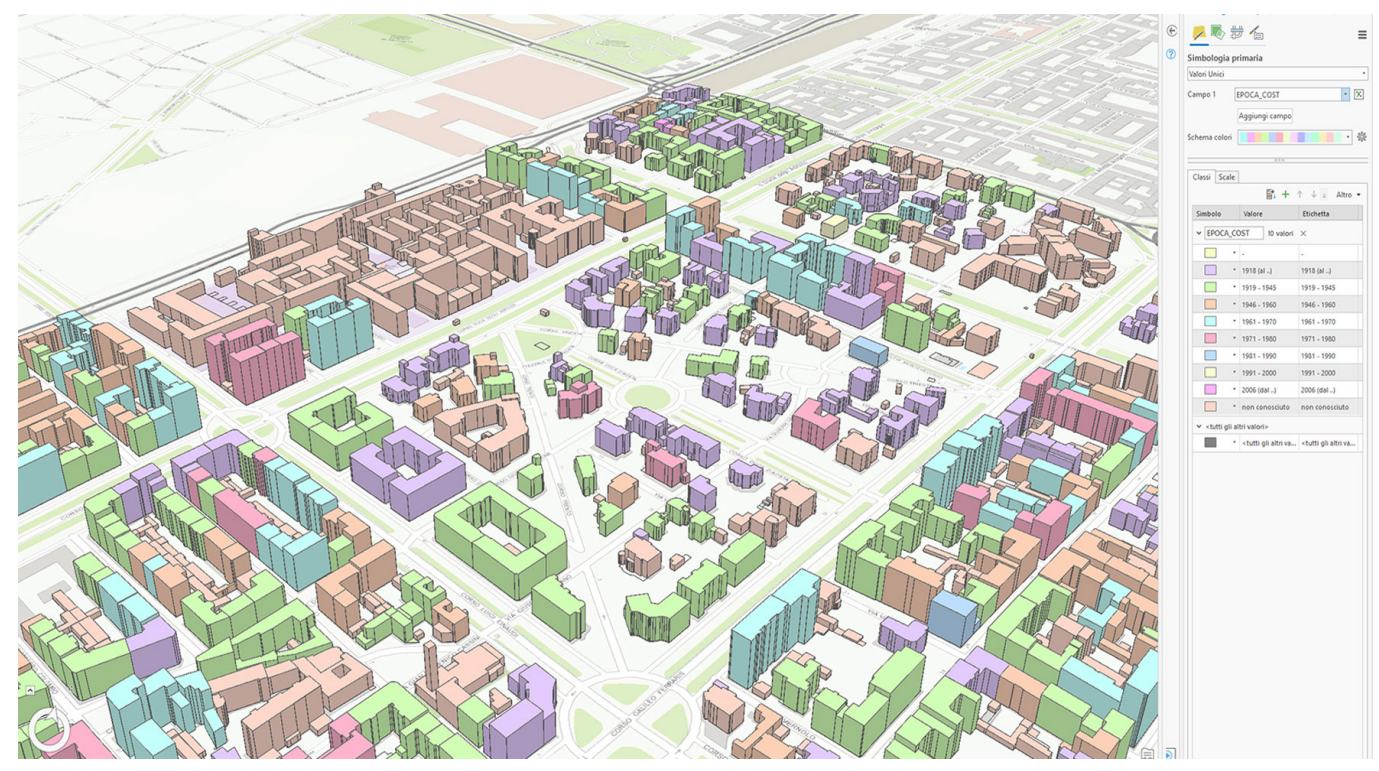


forms of digital representations linked to continuous social changes [Graham et al. 20 I2]. Finally, it is possible to connect urban representations more and more with the single artefact. AR then becomes a container of alphanumeric and geometric data in which each single action, carried out through a sequence of instructions, relates the data extrapolated from external databases and reproduces the correct display on the geometric model through chromatic indexing as shown in figure 5.

In the same way, for each single building it is possible to visualize specific data from BIM models, superimposing on the real model, for example, maintenance, conservation and management information, that the digital model collects. The advantage of this type of display is to be able to compare reliability of information, to program, in the example, targeted interventions to reduce degradation and encourage ordinary maintenance. Thanks to interoperability between data from GIS and BIM, AR systematically returns and catalogs all information necessary to integrate traditional methods of representation. In this sense, its use at the moment of choice appears extremely interesting.

\section{Conclusions}

The study, carried out so far theoretically, shows that, according to actors involved and system analyzed, multiple needs will be satisfied, by designing and implementing appropriate work processes. The latter, organized in stages, must be able to describe the elements involved and to dominate the numerous variables involved, leading to a simplification of initial problem and providing objective criteria with which to make choices. Careful and detailed research of available information (of buildings, of territory, of infrastructures etc.), to be assembled in a single database, facilitates accessibility and reduces systematic errors. As regards private real estate sector, for example, among existing databases useful to populate the model there are those managed by territorial authorities or public administrations. Some of the most interesting are those of Real Estate Market Observatory and of Land Registry (Revenue Agency); the database on energy improvement interventions of ENEA (National Agency for New Technologies, Energy and Sustainable Economic Development); those of ISTAT (National Statistics Institute), which contain information on household consumptions and habits.

Future research developments intend to test the model on a simple case of location choice in the area of the city of Turin, with a measure, on a sample of users of the community, of
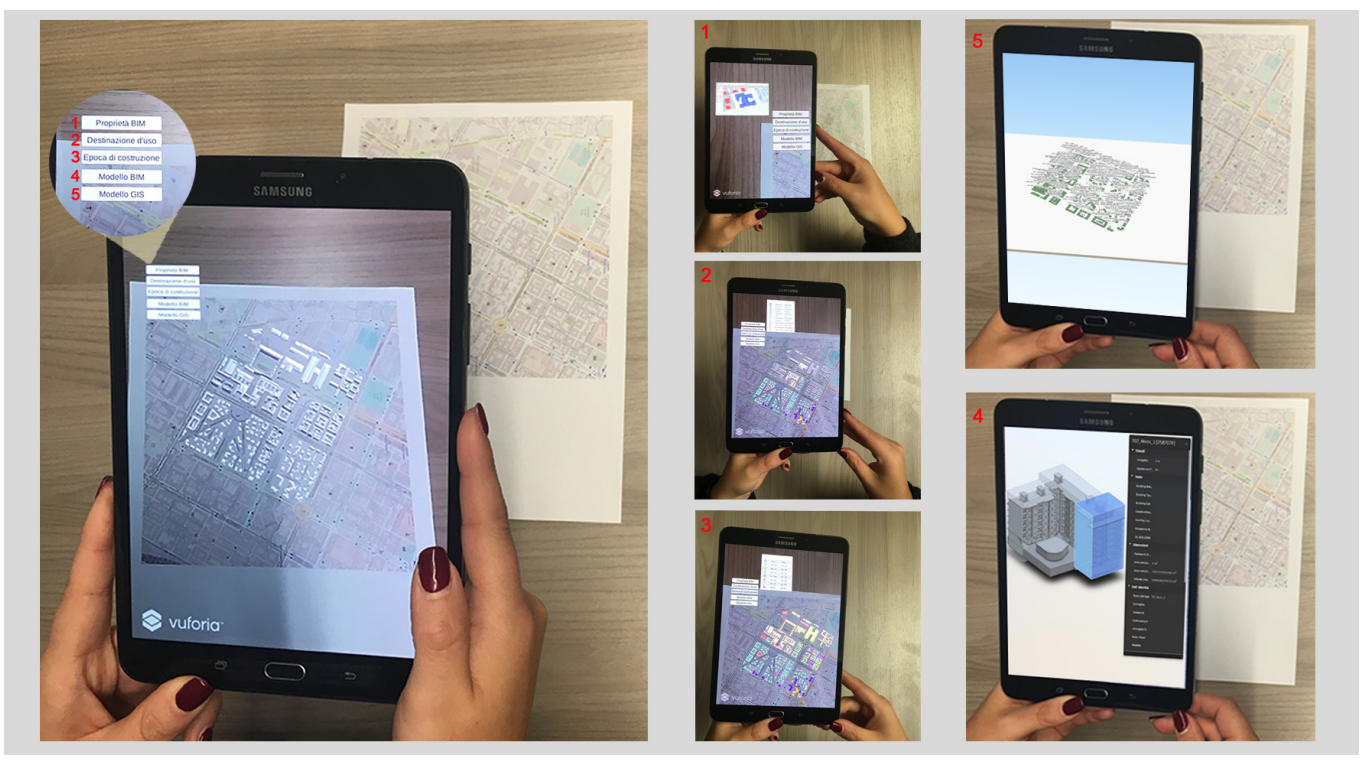
perception of opportunities and of the support degree in the choice, offered by the whole of analysed tools. The wide possibilities of use and its ability to make users memorize codes [Ismail et al. 2009] make AR environment a collaborative and interactive virtual space that can make citizens talk through personalized interfaces and thus make them more involved in choices that public policies operate within the context, in this case urban. Furthermore, multiple databases can be filtered and modified using AR as a simple visualization dashboard. Changes are transferred within a common platform that processes and transforms big data into flexible information systems. Multiple stakeholders are able to establish new relationships in harmony with the surrounding context, evaluating for example correlations between buildings, users and information from heterogeneous and disaggregated databases [Wang et al. 2012].

\section{References}

Azhar Salman (20I I). Building Information Modeling (BIM): Trends, Benefits, Risks, and Challenges for the AEC Industry. In Leadership and Management in Engineering, volume II, issue 3, pp. 24I-252.

Enciclopedia della Matematica Treccani (20I3). Ad vocem: <http://www.treccani.it/enciclopedia/sistema-complesso_\%28Enciclopedia-della-Matematica\%29/>.

Graham Mark, Zook Matthew, Boulton Andrew (20I2). Augmented reality in urban places: contested content and the duplicity of code. In Transactions of Geographical Information Science, volume 38, issue 3, pp. 464-479.

Hardin Brad (2009). BIM and Construction Management: Proven Tools, Methods, and Workflows. Hoboken: John Wiley \& Sons.

Ismail Ajune Wanis, Bin Mohd Shahrizal (2009). Collaborative Augmented Reality: Multi-user Interaction in Urban Simulation. In Halimah Badioze Zaman et al. (eds.). IVIC '09: Proceedings of the I st International Visual Informatics Conference on Visual Informatics: Bridging Research and Practice. Kuala Lumpur (Malaysia), I I- 3 novembre 2009, pp. 37 I-39I. Berlino: Springer.

Klopfer Eric, Squire Kurt (2008). Environmental Detectives: the development of an augmented reality platform for environmental simulations. In Educational Technology Research and Development, 56, pp. 203-228.

Mecca Umberto et al. (2019). Mapping maintenance regulations: a methodological framework to improve territorial resilience. In 19th International Multidisciplinary Scientific GeoConference SGEM 20 19. 2. Hydrology and Water Resources, pp. 229-244.

Moglia Giuseppe, Del Giudice Matteo, Rebaudengo Manuela (2018). The model of the city: data variety, operability and interfaces. In Salerno Rossella (a cura di). Rappresentazione/Materiale/lmmateriale. Atti del $40^{\circ}$ Convegno Internazionale dei Docenti delle Discipline della Rappresentazione. Milano I3-15 settembre, pp. I83- I86. Roma: Gangemi.

Moglia Giuseppe, Rebaudengo Manuela, Ruffino Pablo Angel (2019). “DigitalTwin” Utopia? In Belardi Paolo (a cura di). Riflessioni. L'arte del disegno / II disegno dell'arte Atti del $40^{\circ}$ Convegno Internazionale dei Docenti delle Discipline della Rappresentazione. Perugia 19-2I settembre 2019, pp. 1297-1302. Roma: Gangemi.

Osello Anna, Ugliotti Francesca Maria (20 I7). BIM verso il catasto del futuro; Conoscere, digitalizzare, condividere. II caso studio della città di Torino. Roma: Gangemi.

Prizzon Francesco et al. (2006). La programmazione di opere pubbliche in Piemonte: il caso dei programmi integrati di sviluppo locale (P.I.S.L.). In Atti della XXVII Conferenza Italiana di Scienze Regionali (AISRe). Pisa I2-I4 ottobre 2006.

Prizzon Francesco, Rebaudengo Manuela (20I5). Quale futuro per la valutazione degli investimenti pubblici? Click Day vs. Selezione. In LaborEst, n. 10, pp. 242 I-3 187. <http://pkp.unirc.it/ojs/index.php/LaborEst>.

Wang Xiangyu et al. (2012). A conceptual framework for integrating building information modeling with augmented reality. In Automation in Construction, volume 34, pp. 37-44.

Worboys Michael F., Duckham Matt (2004). GIS: A Computing Perspective. Boca Raton: CRC Press.

\section{Authors}

Daniela De Luca, Politecnico di Torino, daniela.deluca@polito.it

Umberto Mecca, Politecnico di Torino, umberto.mecca@polito.it

Giuseppe Moglia, Politecnico di Torino, giuseppe.moglia@polito.it

Manuela Rebaudengo, Politecnico di Torino, manuela.rebaudengo@polito.it

To cite this chapter: De Luca Daniela, Mecca Umberto, Moglia Giuseppe, Rebaudengo Manuela (2020). Realtà Aumentata con GIS e BIM a servizio dei processi di scelta complessa/Augmented Reality with GIS and BIM at the service of complex choice processes. In Arena A., Arena M., Brandolino R.G., Colistra D., Ginex G., Mediati D., Nucifora S., Raffa P. (a cura di). Connettere. Un disegno per annodare e tessere. Atti del $42^{\circ}$ Convegno Internazionale dei Docenti delle Discipline della Rappresentazione/Connecting. Drawing for weaving relationships. Proceedings of the 42th International Conference of Representation Disciplines Teachers. Milano: FrancoAngeli, pp. 390-403. 